\begin{tabular}{|c|l|}
\hline Title & Mitochondria independent induction of Fas mediated apoptosis by MSSP. \\
\hline Author(s) & Nomura, Jun; Matsumoto, Ken_Ichi; Iguchi-A riga, Sanae M M; A riga, Hiroyoshi \\
\hline Citation & Oncology reports, 14(5), 1305-1309 \\
\hline Issue Date & 2005-11 \\
\hline Doc URL & http://hdl.handle.net/2115/53731 \\
\hline Type & article \\
\hline File Information & 161_Ariga_2005_Oncol_Rep.pdf \\
\hline
\end{tabular}

Instructions for use 


\title{
Mitochondria-independent induction of Fas-mediated apoptosis by MSSP
}

\author{
JUN NOMURA ${ }^{1}$, KEN-ICHI MATSUMOTO ${ }^{1}$, SANAE M.M. IGUCHI-ARIGA ${ }^{2}$ and HIROYOSHI ARIGA ${ }^{1}$ \\ ${ }^{1}$ Graduate School of Pharmaceutical Sciences, Hokkaido University, Kita 12, Nishi 6, Sapporo 060-0812; \\ ${ }^{2}$ Graduate School of Agriculture, Hokkaido University, Kita 9, Nishi 9, Sapporo 060-8589, Japan
}

Received June 28, 2005; Accepted August 8, 2005

\begin{abstract}
Fas-mediated apoptosis has been proposed to play an important role in homeostasis. Fas triggers apoptosis after stimulation by its ligand FasL or the Fas ligand agonist anti-Fas antibody through a mitochondria-dependent or -independent pathway, and MSSP has been identified as a transcription factor that regulates the c-myc gene and was later found to positively or negatively regulate a variety of genes, including $\alpha$-smooth actin, MHC class I, MHC class 2 and the thyrotropin receptor. We further found that expression of the Fas gene was repressed, resulting in abrogation of the Fas-mediated induction of apoptosis both in Mssp-knockout mice and primary thymocytes. MSSP was then found to stimulate promoter activity of the Fas gene by binding to a specific region. In this study, to identify the MSSP-dependent Fas-induced apoptosis pathway, primary fibroblasts from MSSP (+/+) and MSSP (-/-) cells were treated with the combination of interleukin $1-\beta$ and interferon- $\gamma$ and expression of the Fas gene was examined. The results showed that the Fas gene was expressed at the same levels in the two cell types. Furthermore, when these cells were treated with the anti-Fas antibody, it was found that cytochrome $C$ was not released in the cytosol and that activations of caspase 8 and caspase 3 occurred in primary fibroblasts from MSSP (+/+) cells but not from MSSP (-/-) cells. These results indicate that Fas-mediated apoptosis induced by MSSP occurs independently of mitochondria.
\end{abstract}

\section{Introduction}

MSSP family proteins have been identified as proteins that directly bind to the single- or double-strand of $21 \mathrm{bp}$, a putative DNA replication origin and transcriptional enhancer (1-3). Human cDNAs encoding MSSP-1 (3), MSSP-2 (4), Scr2, Scr3 (5) and RBMS3 (6) have been independently cloned and shown to be MSSP family proteins (7). MSSP-1, MSSP-2 and Scr2 are alternative splicing variants of the human MSSP

Correspondence to: Dr Hiroyoshi Ariga, Graduate School of Pharmaceutical Sciences, Hokkaido University, Kita 12, Nishi 6, Kita-ku, Sapporo 060-0812, Japan

E-mail: hiro@pharm.hokudai.ac.jp

Key words: MSSP, apoptosis, Fas, mitochondria, caspase gene 2, which is located at $2 q 24$ in human chromosome 7 (8). The MSSPs that bind to c-Myc have been shown to stimulate myc/ras cooperative transforming activity (9), induce apoptosis (10), stimulate DNA replication by binding to DNA polymerase alpha (11), and play a role in transcriptional regulation of the genes encoding $\alpha$-smooth muscle actin (12), c-Myc (11), thyrotropin receptor (13), MHC class II (14) and MHC class I (15) genes. Thus, MSSPs have pleiotropic functions in cells.

We have generated MSSP-deficient mice by disrupting the Mssp gene in embryonic stem cells. The reduced ratio of littermates of homozygous Mssp (-/-) mice was found to be due to the decreased concentration of progesterone in female mice, which affects the preimplantation embryo (16). We then found reduced expression of the Fas gene in MSSPdeficient mice and their primary thymocytes, resulting in abrogation of Fas-mediated apoptosis (17). Furthermore, MSSP was found to act as a positive transcription factor for the Fas gene by binding to the Fas gene promoter (17).

Fas (CD95, Apo-1) is a receptor for Fas ligand (CD95L) and both are required for immune homeostasis (reviewed in ref. 18). Fas or its family, $\mathrm{TNF} \alpha$, triggers an apoptotic cascade by forming a complex (DISC) containing a death receptor, adaptor protein and procaspase 8 (19-21). There are two distinct signaling pathways for Fas-induced apoptosis: one depends on activation of caspase 8 by cleavage of procaspase 8 at the DISC, resulting in activations of downstream caspases, including caspase 3 or 7 , and the other does not need activation of caspase 8 at the DISC, leading to activation of the mitochondria-induced apoptosis signal (22). In the latter case, activated caspase 8 cleaves a BH3-only protein, Bid $(23,24)$, which then activates proapoptotic molecules, Bax or Bak, resulting in induction of the mitochondrial release of cytochrome $C$ (25-27). Although we showed that MSSP activates expression of the Fas gene, it is still not clear which pathways are used for MSSP-activated Fas.

In this study, we found that cytochrome $C$ was not released from mitochondria and that caspase 8 was activated in cell lines established from MSSP-deficient mice, indicating that Fas-mediated apoptosis by MSSP occurs independently of mitochondria.

\section{Materials and methods}

Reagents and antibodies. Recombinant mouse IL-1ß and IFN- $\gamma$ were purchased from Sigma. Commercially available 
monoclonal antibodies against cytochrome $c$ (7H8.2C12, Pharmingen), mitochondrial complex I 30-kDa subunit (3F9, Molecular Probes), and B-actin (MAB1501R, Chemicon) were used. An anti-MSSP-1 antibody against the peptide corresponding to amino acids 343-370 of human MSSP-1, which were described previously (16), was used for Western blotting. A hamster anti-mouse Fas monoclonal antibody (Jo2, BD Pharmingen) and hamster nonimmune $\mathrm{IgG}$ (Pharmingen) were used for induction of apoptosis.

Cell lines. Primary fibroblasts derived from wild-type and MSSP-deficient mice were cultured in Dulbecco's modified Eagle's medium (Nissui, Tokyo) supplemented with $10 \%$ fetal bovine serum (JRH Biosciences, USA).

$R T$-PCR. Total RNAs were extracted from primary fibroblasts derived from wild-type and MSSP-deficient mice by using Isogen (Nippon Gene), and cDNA was synthesized using the oligo dT primer and BcaBEST polymerase (Takara). The first strand of cDNA products was amplified with specific primers for the first $5 \mathrm{~min}$ at $94^{\circ} \mathrm{C}$, for $1 \mathrm{~min}$ at $94^{\circ} \mathrm{C}$, for $1 \mathrm{~min}$ at $55^{\circ} \mathrm{C}$, and then for 30 cycles of $1 \mathrm{~min}$ at $72^{\circ} \mathrm{C}$ and $1 \mathrm{~min}$ at $72^{\circ} \mathrm{C}$. The nucleotide sequences of the sense and antisense primers were described previously $(16,17)$. The amplified products were separated on a $2 \%$ agarose gel and stained with ethidium bromide. Intensities of bands were measured using NIH image software.

Induction of apoptosis in cultured fibroblasts. Primary fibroblasts were treated with $10 \mu \mathrm{g} / \mathrm{ml}$ cycloheximide and $500 \mathrm{ng} / \mathrm{ml}$ of an anti-Fas antibody (Jo2, BD PharMingen) or non-specific hamster IgG (BD PharMingen). Twelve hours after incubation at $37^{\circ} \mathrm{C}$, expression levels of mRNAs were examined by RT-PCR. Cell viability was then measured using a Cell Counting Kit-8 (Dojin Laboratories, Kumamoto) according to the manufacturer's protocol. Briefly, fibroblasts were cultured in 96-well plates and treated with the anti-Fas antibody for $6,12,24$ and $36 \mathrm{~h}$. After treatment of cells with the anti-Fas antibody, $10 \mu \mathrm{l}$ of a mixture containing $5 \mathrm{mM}$ WST-8, $0.2 \mathrm{mM}$ of methoxy PMS and $150 \mathrm{mM}$ of $\mathrm{NaCl}$ was added to the cells and incubated for 1-3 h. The absorbance at $450 \mathrm{~nm}$ of the mixture was then measured by a microplate reader.

Western blot analysis. Proteins were prepared from the cells with a lysis buffer containing $250 \mathrm{mM}$ sucrose, $10 \mathrm{mM}$ Tris$\mathrm{HCl}$ (pH 7.5), $5 \mathrm{mM}$ EDTA, $50 \mathrm{mM} \mathrm{KCl,} 5 \mathrm{mM} \mathrm{MgCl} 2,5 \mathrm{mM}$ EGTA, $1 \mathrm{mM}$ DTT and $1 \mathrm{mM}$ PMSF, followed by 30 strokes of homogenization using a Dounce homogenizer. Unbroken cells and nuclei were precipitated by centrifugation at $600 \mathrm{~g}$ for $5 \mathrm{~min}$. Mitochondrial fractions were collected from the supernatant by centrifugation at $12,000 \mathrm{~g}$ for $10 \mathrm{~min}$ and suspended with the lysis buffer. Proteins were then separated on $15 \%$ SDS-containing polyacrylamide gel and transferred to a nitrocellulose membrane. After the membrane had been blocked with a buffer containing $20 \mathrm{mM}$ Tris- $\mathrm{HCl}(\mathrm{pH} 7.5)$, $137 \mathrm{mM} \mathrm{NaCl}, 0.1 \%$ Tween-20 (TBST) and 10\% milk for $1 \mathrm{~h}$ at room temperature, the membrane was reacted with a $1 / 1000$ dilution of anti-cytochrome $C$, anti-mitochondrial complex I 30-kDa subunit, anti-MSSP-1 and anti- $\beta$-actin

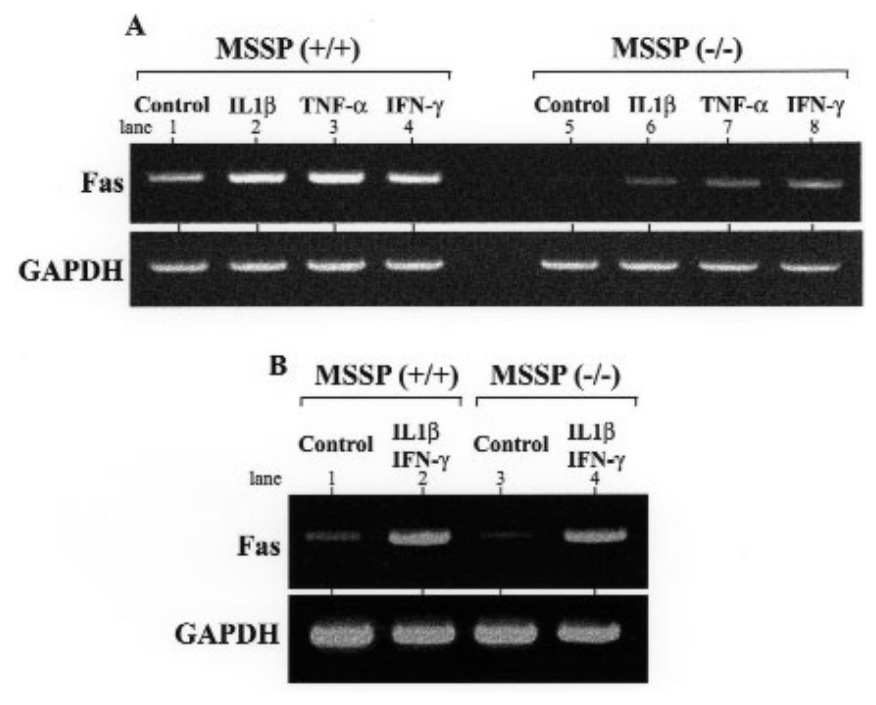

Figure 1. Expression of the Fas gene after treatment of the cells with cytokines. A, primary fibroblasts from MSSP (+/+) and MSSP (-/-) cells were treated with $100 \mathrm{ng} / \mathrm{ml}$ of IL-1ß, TNF- $\alpha$ or IFN- $\gamma$ for $6 \mathrm{~h}$, and expression levels of Fas and GAPDH mRNAs were examined by RT-PCR as described in Materials and methods. B, the cells were incubated with $100 \mathrm{ng} / \mathrm{ml}$ of the combination of IL- 13 and TNF- $\alpha$ for $6 \mathrm{~h}$, and expression levels of Fas and GAPDH mRNAs were examined by RT-PCR.

antibodies for $1 \mathrm{~h}$ at room temperature. The membrane was then washed with TBST, incubated with Alexa Flour 680conjugated anti-mouse IgG or Alexa Flour 680-conjugated anti-rabbit IgG (Molecular Probes) for $1 \mathrm{~h}$ at room temperature, and visualized using an Odyssey infrared imaging system (LI-COR Biosciences).

Caspase assays. Caspase 3 and caspase 8 activity in the cells was measured using APOPCYTO Caspase-3 Colorometric Assay and APOPCYTO Caspase-8 Colorometric Assay kits (MBL) according to the manufacturer's instructions.

\section{Results and discussion}

No effect of cytokines on Fas expression in MSSP (-/-) cells. We have previously reported that the expression level of the Fas gene is low in primary fibroblasts derived from MSSPdeficient mice and that MSSP regulates the Fas gene expression as a transcription factor by binding to the Fas promoter region (17). Fas gene expression has been reported to be induced by various cytokines, including IL- $1 \beta, \mathrm{TNF}-\alpha$ and IFN- $\gamma$, in human malignant glioma cells, but simultaneous addition of TNF- $\alpha$ and IFN- $\alpha$ has been shown to abrogate induction of Fas expression (28). Expression of the Fas gene in human thyroid epithelial cells has, on the other hand, been shown to be sensitized by the combination of IL-1B and IFN- $\gamma$ (29). Expression of the Fas gene has also been reported to be regulated by various transcription factors, including $\mathrm{NF}-\kappa \mathrm{B}$ (30-32), AP1 (31), Sp1 (32), Sp3 (33), C/EBP (34) and MSSP (17). We therefore investigated the effects of MSSP on transcription of the Fas gene through various cytokines. Primary fibroblast cells derived from MSSP (+/+) and MSSP (-/-) mice were incubated with $100 \mathrm{ng} / \mathrm{ml}$ of IL-1ß, TNF- $\alpha$ or IFN- $\gamma$ for $6 \mathrm{~h}$, and expression levels of Fas mRNA were examined by RT-PCR (Fig. 1A). As reported previously (17), 

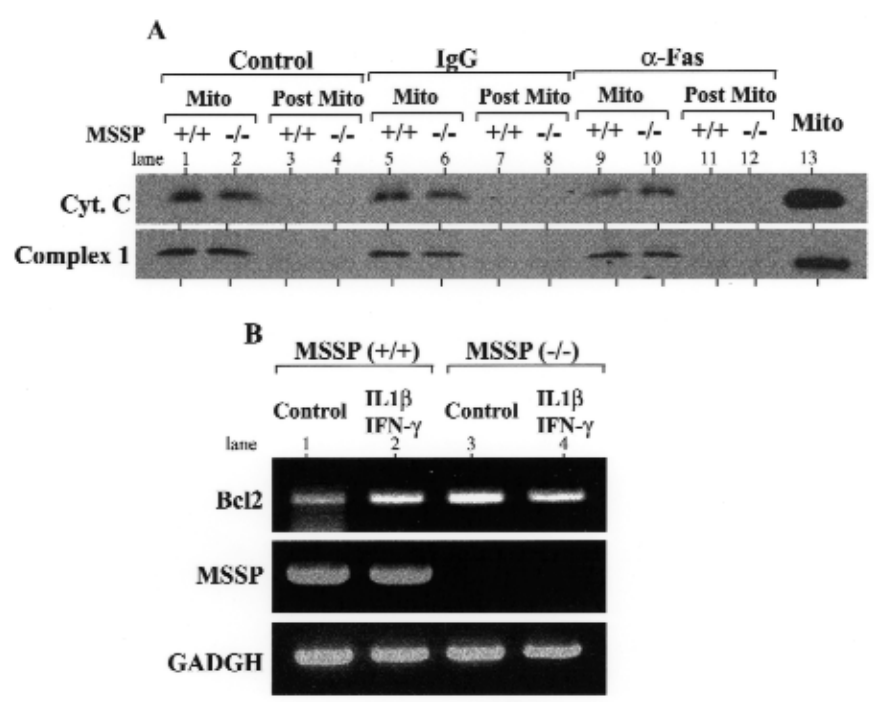

Figure 2. Release of cytochrome $C$ from mitochondria after addition of an anti-Fas antibody to MSSP (+/+) and MSSP (-/-) cells. Primary fibroblasts from MSSP (+/+) and MSSP (-/-) cells were treated with $100 \mathrm{ng} / \mathrm{ml}$ of an anti-Fas antibody or non-specific IgG together with $10 \mu \mathrm{g} / \mathrm{ml}$ of cycloheximide. Twenty-four hours after treatment, cell extracts were prepared and then mitochondrial and cytosolic fractions were separated as described in Materials and methods. Proteins in their fractions were analyzed by Western blotting with anti-cytochrome $C$ and anti-mitochondrial complex 1 antibodies. Mito and Post Mito in Figure 2A indicate mitochondrial and cytosolic fractions, respectively. B, primary fibroblasts from MSSP $(+/+)$ and MSSP (-/-) cells were treated with $100 \mathrm{ng} / \mathrm{ml}$ of IL-1ß and IFN- $\gamma$ for $6 \mathrm{~h}$, and expression levels of Bcl-2, MSSP and GAPDH mRNA were measured by RT-PCR as described in Materials and methods.

a low expression level of Fas mRNA was observed in MSSP (-/-) cells without addition of cytokines (Figs. 1A, lanes 1 and 5). Although addition of all of the cytokines to the cells stimulated expression levels of Fas mRNA, it was found that efficiencies of stimulation were not different in MSSP (+/+) and MSSP (-/-) cells (Fig. 1A, lanes 2-4 and 6-8). Furthermore, while simultaneous treatment of the cells with IL-1ß and IFN- $\gamma$ was found to stimulate expression of Fas
mRNA, it was found that efficiencies of stimulation were not different in MSSP (+/+) and MSSP (-/-) cells (Fig. 1B). These results suggest that MSSP is not related to the signaling pathway of cytokine-induced Fas expression.

No release of cytochrome $C$ from mitochondria to the cytosol in MSSP (-/-) cells. Fas stimulated by addition of an anti-Fas antibody to the cells leads to activation of caspase-8, which then triggers either a pathway of apoptosis that is independent of mitochondria or a pathway of apoptosis that is dependent on mitochondria. In the mitochondria-dependent pathway, cytochrome $C$ is translocated from mitochondria to the cytosol. To investigate whether the MSSP-dependent Fas signal is linked to the mitochondorial pathway, MSSP (+/+) and MSSP (-/-) cells were treated with an anti-Fas antibody for $24 \mathrm{~h}$ and proteins in the mitochondrial and cytosolic fractions were analyzed by Western blotting with an anti-cytochrome $C$ antibody (Fig. 2A). Filters were also blotted with an antiNADH-ubiquinon oxidoreductase (a 30-kDa subunit of mitochondrial complex I) to show purity of fractions. The $30-\mathrm{kDa}$ subunit of mitochondrial complex I was observed in the mitochondrial fraction but not in the cytosolic fraction/postmitochondrial faction and cytochrome $C$ was also observed only in the mitochondrial fraction both in MSSP $(+/+)$ and MSSP (-/-) cells before and after treatment of the cells with the anti-Fas antibody. Since it has been reported that mitochondrial membrane permeability was regulated by the anti-apoptotic molecule, Bcl-2, and that simultaneous treatment of cells with IL-1B and IFN- $\gamma$ decreased the level of bcl-2 protein (29), the expression levels of bcl-2 mRNA in MSSP (+/+) and MSSP (-/-) cells were analyzed by RT-PCR (Fig. 2B). The results showed that the expression levels of $\mathrm{Bcl}-2$ normalized to those of GAPDH were not different in MSSP (+/+) and MSSP (-/-) cells. These results indicate that the MSSPdependent Fas signal occurs independently of mitochondria.

Activation of caspases 8 and 3 after apoptosis stimulation only in MSSP (+/+) cells. To further elucidate the pathway of the MSSP-dependent Fas signaling, the activity of caspase 8

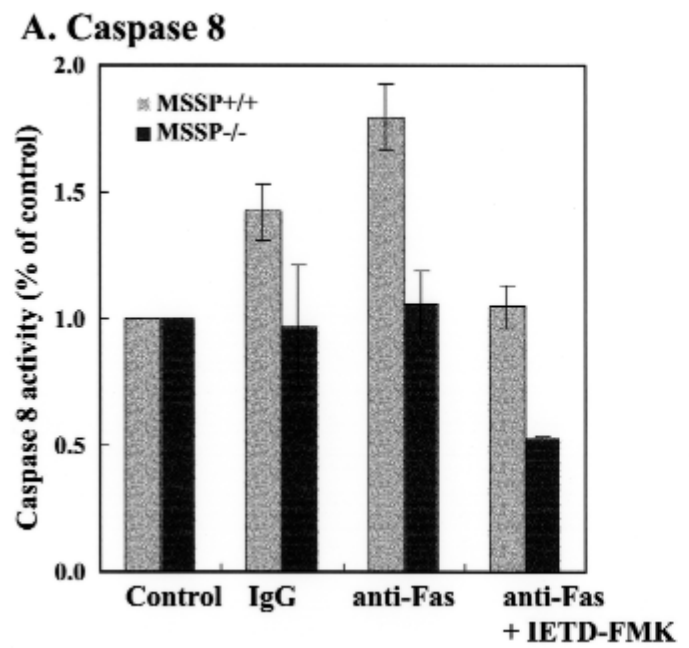

\section{B. Caspase 3}

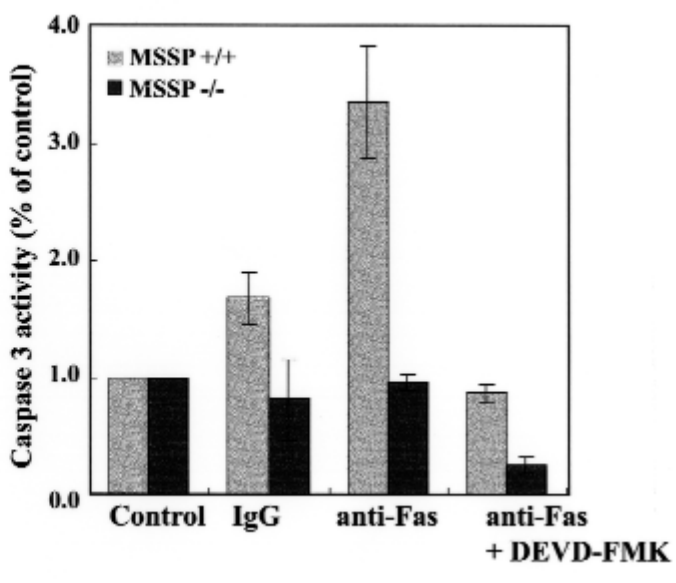

Figure 3. Activation of caspases 8 and 3 after stimulation of apoptosis in MSSP (+/+) cells. Primary fibroblasts from MSSP (+/+) and MSSP (-/-) cells were treated with $100 \mathrm{ng} / \mathrm{ml}$ of an anti-Fas antibody or non-specific IgG together with $10 \mu \mathrm{g} / \mathrm{ml}$ of cycloheximide. Twenty-four hours after treatment, cell extracts were prepared and their caspase 3 (A) and caspase 8 (B) activities were measured as described in Materials and methods. 


\section{A. $500 \mathrm{ng} / \mathrm{ml}$}

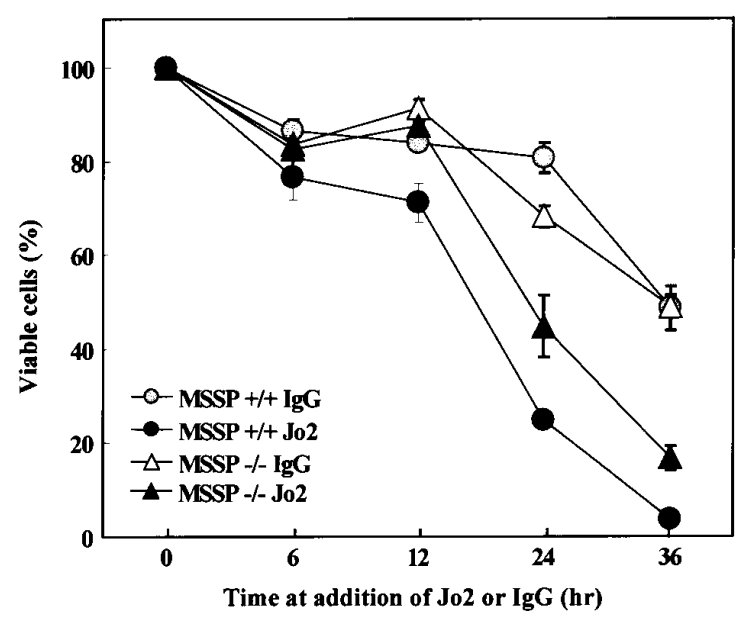

B. $1000 \mathrm{ng} / \mathrm{ml}$

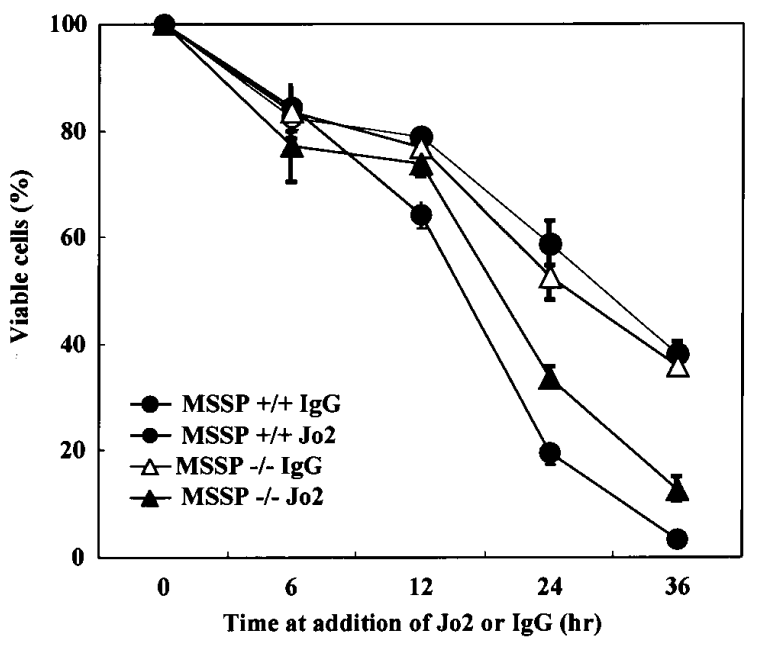

Figure 4. Abrogation of cell death by depletion of MSSP. Primary fibroblasts from MSSP (+/+) and MSSP (-/-) cells were treated with $500 \mathrm{ng} / \mathrm{ml}$ (A) or $1000 \mathrm{ng} / \mathrm{ml}$ (B) of an anti-Fas antibody or non-specific IgG together with $10 \mu \mathrm{g} / \mathrm{ml}$ of cycloheximide. Twenty-four hours after treatment, cell viability was measured as described in Materials and methods.

and caspase 3 was measured after MSSP (+/+) and MSSP (-/-) cells had been treated with an anti-Fas antibody using a fluorescent peptide as a substrate (Fig. 3). Stimulation of caspase 8 activity by addition of the anti-Fas antibody was stronger than that by addition of non-specific IgG in MSSP $(+/+)$ cells but not in MSSP (-/-) cells, and the activity was inhibited by addition of IETD-FMK, an inhibitor of caspase 8 (Fig. 3A). Furthermore, activation of caspase 3 , a downstream caspase, was found to occur in MSSP (+/+) cells but not in MSSP (-/-) cells (Fig. 3B). These results suggest that MSSP-dependent Fas-induced apoptosis occurs through activation of caspase 8 followed by activation of caspase 3 .

Sensitization of MSSP (+/+) cells to Fas-induced apoptosis. Susceptibility of MSSP (+/+) and MSSP (-/-) cells to Fasinduced apoptosis was then examined. The cells were treated with $500 \mathrm{ng} / \mathrm{ml}$ or $1000 \mathrm{ng} / \mathrm{ml}$ of an anti-Fas antibody or nonspecific IgG for $24 \mathrm{~h}$ and cell viabilities were measured by an MTT assay (Fig. 4). The results showed that MSSP (+/+) cells treated with the anti-Fas antibody, but not those treated with non-specific IgG, died faster than MSSP (-/-) cells throughout the period of addition of anti-Fas antibodies, indicating that Fas-induced apoptosis depends on the expression of MSSP.

Fas triggers apoptosis after stimulation by its ligand FasL or the Fas ligand agonist anti-Fas antibody through a mitochondria-dependent or -independent pathway. Commitment to either pathway depends on activation of caspase 8 at the DISC, a complex containing a death receptor, adaptor protein, and procaspase- 8 . While activation of caspase 8 is needed in both pathways, activation of caspase 8 at the DISC occurs only in the mitochondria-independent pathway. In the mitochondriadependent pathway, caspase 8 cleaves a BH3-only protein, Bid, which then releases cytochrome $C$ from mitochondria to the cytoplasm (19-24). In this study, we showed that while Fas-induced apoptosis occurred upon stimulation of Fas strongly in MSSP (+/+) cells and weakly in MSSP (-/-) cells, cytochrome $C$ was not released from mitochondria upon stimulation of Fas in either MSSP (+/+) or MSSP (-/-) cells, indicating that MSSP-dependent Fas-induced apoptosis occurs in a mitochondria-independent manner. Furthermore, treatment of both MSSP (+/+) and MSSP (-/-) cells with the combination of interleukin 1- $\beta$ and interferon- $\gamma$ did not affect the expression level of the Fas gene. Since Fas gene promoter activity has been reported to be activated by $\mathrm{NF \kappa B}$ after treatment with the combination of interleukin $1-\beta$ and interferon- $\gamma$ (29) and since the recognition sites of NFKB and MSSP are aligned separately on the Fas gene promoter (17), activation of the Fas gene by MSSP after treatment of the cells with the antiFas antibody is thought to occur through the independent pathway after treatment with interleukin $1-\beta$ and interferon- $\gamma$.

\section{Acknowledgments}

We thank Yoko Misawa and Kiyomi Takaya for their technical assistance. This work was supported by grants-in-aid from the Ministry of Education, Science, Culture, Sports.

\section{References}

1. Iguchi-Ariga SMM, Okazaki T, Itani T, Ogata M, Sato Y and Ariga $\mathrm{H}$ : An initiation site of DNA replication with transcriptional enhancer activity present upstream of c-myc gene. EMBO J 7: 3135-3142, 1988.

2. Ariga H, Imamura $Y$ and Iguchi-Ariga SMM: DNA replication origin with transcriptional enhancer activity share the c-myc protein binding sequences. EMBO J 8: 4273-4279, 1989.

3. Negishi Y, Nishita Y, Saegusa Y, Kakizaki I, Galli I, Kihara F, Tamai K, Miyajima N, Iguchi-Ariga SMM and Ariga H: Identification and cDNA cloning of single-stranded DNA binding proteins that interact with the region upstream of the human c-myc gene. Oncogene 9: 1133-1143, 1994.

4. Takai T, Nishita Y, Iguchi-Ariga SMM and Ariga H: Molecular cloning of MSSP- 2, a c-myc gene single strand binding protein: characterization of binding specificity and DNA replication activity. Nucleic Acids Res 22: 5576-5581, 1994.

5. Kanaoka Y and Nojima H: SCR: novel human suppressors of cdc $2 /$ cdc13 mutants of Schizosaccharomyces pombe harbour motifs for RNA binding proteins. Nucleic Acids Res 22: 2687-2693, 1994.

6. Penkov D, Ni R, Else C, Pinol-Roma S, Ramirez F and Tanaka S: Cloning of a human gene closely related to the genes coding for the c-myc single-strand binding proteins. Gene 243: 27-36, 2000.

7. Haigermoser C, Fujimoto M, Iguchi-Ariga SMM and Ariga H: Cloning and characterization of the genomic DNA of the human MSSP gene. Nucleic Acids Res 24: 3846-3857, 1996. 
8. Fujimoto M, Matsumoto K, Iguchi-Ariga SMM and Ariga $\mathrm{H}$ Structure and comparison of genomic and complementary DNAs of mouse MSSP, a c-Myc binding protein. Int J Oncol 16: 245-251, 2000.

9. Niki T, Izumi S, Saegusa Y, Taira T, Takai T, Iguchi-Ariga SMM and Ariga H: MSSP promotes the ras/myc cooperative cell transforming activity by binding to C-MYC. Genes Cells 5: $127-141,2000$

10. Iida M, Taira T, Ariga H and Iguchi-Ariga SMM: Induction of apoptosis by MSSP, C-MYC binding proteins. Biol Pharm Bull 20: 10-14, 1997

11. Niki T, Galli I, Ariga H and Iguchi-Ariga SMM: MSSP, a protein binding to an origin of replication in the c-myc gene, interacts with a catalytic subunit of DNA polymerase alpha and stimulates its polymerase activity. FEBS Lett 475: 209-212, 2000.

12. Kimura K, Saga H, Hayashi K, Obata H, Chimori Y, Ariga H and Sobue K: c-Myc gene single-strand binding protein-1, MSSP-1, suppresses transcription of a smooth muscle actin gene in chicken visceral smooth muscle cells. Nucleic Acids Res 26 : 2420-2425, 1998.

13. Shimura H, Shimura Y, Ohmori M, Ikuyama S and Kohn LD: Single strand DNA-binding proteins and thyroid transcription factor-1 conjointly regulate thyrotropin receptor gene expression. Mol Endocrinol 9: 527-539, 1995

14. Ohmori M, Ohta M, Shimura H, Shimurat Y, Suzuki K and Kohn LD: Cloning of the single strand DNA-binding protein important for maximal expression and thyrotropin (TSH)induced negative regulation of the TSH receptor. Mol Endocrinol 10: 1407-1424, 1996.

15. Balducci-Silano PL, Suzuki K, Ohta M, Saito I, Ohmori M, Montani V, Napolitano G, Shong M, Taniguchi SI, Pietrarelli M, Lavaroni S, Mori A, Singer DS and Kohn LD: Regulation of major histocompatibility (MHC) class II human leukocyte antigen-DR alpha gene expression in thyrocytes by single strand binding protein-1, a transcription factor that also regulates thyrotropin receptor and MHC class I gene expression. Endocrinol 139: 2300-2313, 1998.

16. Fujimoto M, Matsumoto K, Iguchi-Ariga SMM and Ariga H: Disruption of MSSP, c-myc single-strand binding protein, leads to embryonic lethality in some homozygous mice. Genes Cells 6: 1067-1075, 2001

17. Nomura J, Matsumoto K, Iguchi-Ariga SMM and Ariga H: Positive regulation of Fas gene expression by MSSP and abrogation of Fas-mediated apoptosis induction in MSSPdeficient mice. Exp Cell Res 305: 324-332, 2005.

18. Nagata S: Apoptosis by death factor. Cell 88: 355-365, 1997.

19. Kischkel FC, Hellbardt S, Behrmann I, Germer M, Pawlita M, Krammer PH and Peter ME: Cytotoxicity-dependent APO-1 (Fas/CD95)-associated proteins form a death-inducing signaling complex (DISC) with the receptor. EMBO J 14: 5579-5588, 1995.

20. Boldin MP, Goncharov TM, Goltsev YV and Wallach D: Involvement of MACH, a novel MORT1/FADD-interacting protease, in Fas/APO-1- and TNF receptor-induced cell death. Cell 85: 803-815, 1996.
21. Wallach D, Varfolomeev EE, Malinin NL, Goltsev YV, Kovalenko AV and Boldin MP: Tumor necrosis factor receptor and Fas signaling mechanisms. Annu Rev Immunol 17: 331-367, 1999.

22. Scaffidi C, Fulda S, Srinivasan A, Friesen C, Li F, Tomaselli KJ, Debatin KM, Krammer PH and Peter ME: Two CD95 (APO1/Fas) signaling pathways. EMBO J 17: 1675-1687, 1998.

23. Li H, Zhu H, Xu CJ and Yuan J: Cleavage of BID by caspase 8 mediates the mitochondrial damage in the Fas pathway of apoptosis. Cell 94: 491-501, 1998.

24. Luo X, Budihardjo I, Zou H, Slaughter C and Wang X: Bid, a $\mathrm{Bcl} 2$ interacting protein, mediates cytochrome $\mathrm{c}$ release from mitochondria in response to activation of cell surface death receptors. Cell 94: 481-490, 1998.

25. Desagher S, Osen-Sand A, Nichols A, Eskes R, Montessuit S, Lauper S, Maundrell K, Antonsson B and Martinou JC: Bidinduced conformational change of Bax is responsible for mitochondrial cytochrome $\mathrm{c}$ release during apoptosis. J Cell Biol 144: 891-901, 1999.

26. Eskes R, Desagher S, Antonsson B and Martinou JC: Bid induces the oligomerization and insertion of Bax into the outer mitochondrial membrane. Mol Cell Biol 20: 929-935, 2000.

27. Wei MC, Zong WX, Cheng EH, Lindsten T, Panoutsakopoulou V Ross AJ, Roth KA, MacGregor GR, Thompson CB and Korsmeyer SJ: Proapoptotic BAX and BAK: a requisite gateway to mitochondrial dysfunction and death. Science 292: 727-730, 2001.

28. Weller M, Frei K, Groscurth P, Krammer PH, Yonekawa Y and Fontana A: Anti-Fas/APO-1 antibody-mediated apoptosis of cultured human glioma cells. J Clin Invest 94: 954-964, 1994

29. Mezosi E, Wang SH, Utsugi S, Bajnok L, Bretz JD, Gauger PG, Thompson NW and Baker JR Jr: Induction and regulation of Fas-mediated apoptosis in human thyroid epithelial cells. Mol Endocrinol 19: 804-811, 2005.

30. Chan H, Bartos DP and Owen-Schaub LB: Activation-dependent transcriptional regulation of the human Fas promoter requires NF-kappaB p50-p65 recruitment. Mol Cell Biol 19: 2098-2108, 1999.

31. Harwood FG, Kasibhatla S, Petak I, Vernes R, Green DR and Houghton JA: Regulation of FasL by NF-kappaB and AP-1 in Fas-dependent thymineless death of human colon carcinoma cells. J Biol Chem 275: 10023-10029, 2000.

32. Dudley E, Hornung F, Zheng L, Scherer D, Ballard D and Lenardo M: NF- kappaB regulates Fas/APO-1/CD95- and TCRmediated apoptosis of T lymphocytes. Eur J Immunol 29: 878-886, 1999 .

33. Pang H, Miranda $\mathrm{K}$ and Fine A: Sp3 regulates fas expression in lung epithelial cells. Biochem J 333: 209-213, 1998.

34. Darville MI and Eizirik DL: Cytokine induction of Fas gene expression in insulin-producing cells requires the transcription factors NF-kappaB and C/EBP. Diabetes 50: 1741-1748, 2001. 